\title{
Antidiabetic Activity with N-Hexane, Ethyl-Acetate and Ethanol Extract of Halodule uninervis Seagrass
}

\author{
Ace Baehaki ${ }^{1}{ }^{*}$, Herpandi ${ }^{1}$, Susi Lestari ${ }^{1}$, Muhammad Hendri ${ }^{2}$, Febri Ariska ${ }^{1}$
}

Ace Baehaki ${ }^{1, *}$, Herpandi ${ }^{1}$, Susi Lestari ${ }^{1}$, Muhammad Hendri², Febri Ariska'

'Study Program of Fisheries Product Technology, Faculty of Agriculture, Sriwijaya University, Indralaya, South Sumatera, INDONESIA.

${ }^{2}$ Study Program of Marine Sciences, Faculty of Mathematics and Natural Sciences, Sriwijaya University, Indralaya, South Sumatera, INDONESIA.

\section{Correspondence}

Ace Baehaki

Study Program of Fisheries Product Technology, Faculty of Agriculture, Sriwijaya University, Indralaya, South Sumatera, INDONESIA.

Email: acebaehaki.thi@unsri.ac.id

History

- Submission Date: 02-04-2020;

- Review completed: 28-04-2020;

- Accepted Date: 11-05-2020

DOI : 10.5530/pj.2020.12.115

Article Available online

http://www.phcogj.com/v12/i4

\section{Copyright}

(C) 2020 Phcogj.Com. This is an openaccess article distributed under the terms of the Creative Commons Attribution 4.0 International license.

\section{ABSTRACT}

The purpose of this research was to observe the antidiabetic activity from $\mathrm{N}$-hexane, ethylacetate and ethanol extract of Halodule uninervis seagrass. The antidiabetic activity with extract concentrations of 125 ppm, 250 ppm, 500 ppm, 1000 ppm and 2000 ppm from seagrass extract with ethanol solvent showed that it had the ability as an anti-diabetic agent stronger than seagrass extract with $\mathrm{n}$-hexane and ethyl acetate solvents. Calculation of $\mathrm{IC}_{50}$ of Halodule uninervis seagrass with ethanol extract was $74.99 \mathrm{ppm}$ and ethyl acetate was 1,517,05 ppm. Glukobay as control was 0.27 ppm.

Key words: Antidiabetic, Extract, Haludule uninervis, Seagrass.

\section{INTRODUCTION}

Diabetes mellitus is a metabolic disorder characterized by hyperglycemia and a body imbalance in the metabolism of carbohydrates, fats and proteins. Treatment of diabetes mellitus can be done by giving synthetic drugs, but the use of synthetic drugs can have side effects on users. So the treatment of diabetes mellitus shifts to the use of herbal medicines from plants which are believed to be an $\alpha$-glucosidase inhibitors.

a-Glucosidase enzyme released from the intestinal chorion epithelium is responsible for carbohydrate degradation. A-Glucosidase inhibitors fall into the third category of oral hypoglycemic agents. ${ }^{1}$ Some a-glucosidase inhibitors, such as acarbose and voglibose obtained from natural sources, can effectively control blood glucose levels after food intake and have been used clinically in the treatment of diabetes mellitus. ${ }^{2}$ So far, around 800 plants worldwide have demonstrated antidiabetic potential. ${ }^{3}$ Plants have traditionally been used for the treatment of diabetes mellitus, and they provide a great source of drugs and biological compounds. ${ }^{4}$

Seagrass is a group of flowering plants in the marine environment. Seagrasses have rhizomes, leaves, and true roots and live immersed in the sea which adapt in waters with high salinity. ${ }^{5}$ Habitat of seagrass habitats is rather sandy shallow waters and often found on coral reefs. The same seagrass species can grow in different habitats by showing different forms of growth and groups of seagrass species forming clear stand zones, whether pure or associated with several species. ${ }^{6}$

Seagrasses found in Indonesia have 7 genera, namely Enhalus, Thalassia, Halophila, Halodule, Cymodocea, Syrongidium, and Thalssodendrom. ${ }^{7}$ Halodule seagrass is found from mid tidal to a depth of $20 \mathrm{~m}$, generally at depths between $0-3 \mathrm{~m}$ in sublittoral lagoons and near coral reefs. ${ }^{8}$ Seagrass Halodule sp. the same as plants generally contain bioactive compounds. bioactive compounds are active chemical compounds produced by organisms through the biosynthetic pathway secondary metabolites namely alkaloids, phenols, flavonoids, saponins, terpenoids, steroids, tannins, plobatamine and coumarin. ${ }^{9}$ According to Widuri ${ }^{10}$, flavonoids, steroids, tannins and saponins in ingredients can inhibit $\alpha$-glucosidase activity.

There are many medicinal plants that have been known to be beneficial and can be used as antidiabetic agents. ${ }^{11}$ One plant that has not been widely studied scientifically is used as an antidiabetic agent, namely seagrass Halodule uninervis Therefore it is necessary to conduct further studies regarding the testing of antidiabetic activity with n-hexane, ethyl acetate and ethanol extract in Halodule uninervis.

\section{MATERIALS AND METHODS}

\section{Preparation before extraction}

Seagrass plants before extraction are prepared first: Seagrass washed with running water to remove foreign objects (rocks, sand, shells and so on). Then, it is dried using an oven with a temperature of $31.3^{\circ} \mathrm{C}$ for $3 \times 24 \mathrm{~h}$.

\section{Extraction}

Seagrass plants that have been prepared will be carried out with the following extraction process: seagrass powder is extracted by multilevel maceration using n hexane (nonpolar), ethyl acetate (semipolar), and $70 \%$ ethanol (polar) solvents respectively for $2 \times 24 \mathrm{~h}$ Searching is done three times. The extract obtained from the three types of solvents was concentrated with rotavour, except for ethyl acetate solvents. Ethyl acetate extract was dried in a fume hood.

Antidiabetic activity test (Inhibition of a-Glucosidase Enzymes)

Inhibition of alpha glucosidase activity was tested according to Sancheti ${ }^{12}$, the reaction mixture

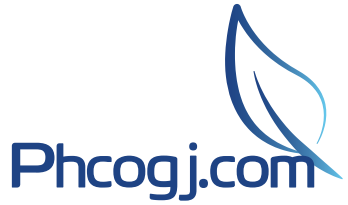

Cite this article: Baehaki A, Herpandi, Lestari S, Hendri M, Ariska F. Antidiabetic Activity with $\mathrm{N}-$ Hexane, Ethyl-Acetate and Ethanol Extract of Halodule uninervis Seagrass. Pharmacogn J. 2020;12(4):805-8. 
consisted of $50 \mu \mathrm{L} 0.1 \mathrm{M}$ phosphate buffer ( $\mathrm{pH} 7$ ), $25 \mu \mathrm{L} 0.5 \mathrm{mM}$ 4-nitrophenyl a-D-glucopyranoside (dissolved in $0.1 \mathrm{M}$ buffer phosphate $\mathrm{pH} 7$ ), $10 \mathrm{uL}$ test sample (concentration of $500 \mathrm{mg} \mathrm{mL}-1$ ) and $25 \mathrm{uL} \alpha$-glucosidase solution (stock solution of $1 \mathrm{mg} \mathrm{mL}^{-1}$ in $0.01 \mathrm{M}$ phosphate buffer $\mathrm{pH} 7$ diluted 0.04 units $\mathrm{mL}^{-1}$ with buffer phosphate $\mathrm{pH}$ 7). This reaction mixture is then incubated at $37^{\circ} \mathrm{C}$ for $30 \mathrm{~min}$. Then, the reaction is added $100 \mu \mathrm{L}$ sodium carbonate $0.2 \mathrm{M}$ solution, then the reaction is calculated absorbance using uv-vis spectrophotometry 410 $\mathrm{nm}$. As a comparison, glucobay solution is used. The inhibition of alpha glucosidase enzyme activity is determined by the formula:

Inhibition $(\%)=(($ Abt-Ast $)) /$ Abt x 100\%

Where :

Abt $=$ corrected absorbance of blanks

Ast $=$ absorbance of the corrected sample

\section{RESULTS AND DISCUSSION}

\section{Antidiabetic activity test (Inhibition of a-Glucosidase} Enzymes)

The testing of antidiabetic activity is using the in-vitro inhibition of the $\alpha$-glucosidase enzyme with $p$-nitrophenol-a-glucosidase as the substrate using seagrass of Halodule uninervis extract with $\mathrm{n}$-hexane (nonpolar), ethyl acetate (semi-polar) and ethanol (polar) solvents as a test sample and glucobay solution as a positive control. Tests were carried out with various extract concentrations in order to determine the effect of various extract concentrations on enzyme inhibition. The concentrations of extracts used were $125 \mathrm{ppm}, 250 \mathrm{ppm}, 500 \mathrm{ppm}$, $1,000 \mathrm{ppm}$ and 2,000 ppm.

The results of the percentage of inhibition of antidiabetic activity in samples of Halodule uninervis with ethanol solvents can be seen in Figure 1.

In Figure 1 it can be seen that the Halodule uninervis sample with ethanol solvent shows the smallest percentage inhibition value found at a concentration of $125 \mathrm{ppm}$ which was $58.78 \%$ and the largest percentage inhibition value was at a concentration of $2,000 \mathrm{ppm}$ which is $94.69 \%$. This shows that the sample using ethanol solvent was an antidiabetic agent. Biocative compounds that play a role in the antidiabetic activity of flavonoids, saponins, steroids, and triterpenoids in phytochemical testing showed positive results found on seagrass. The results of the antidiabetic activuty from extract of Halodule uninervis using ethyl acetate solvents are shown in Figure 2.

In Figure 2 it can be seen that the Halodule uninervis extract with ethyl acetate solvent shows that the sample with a concentration of 2,000 ppm has an antidiabetic inhibition of $18.08 \%$. This shows that seagrass extract using ethyl acetate solvents has a weak inhibition in antidiabetic activity. This can be seen in percent inhibition, the sample can inhibit a-glucosidase $>2,000 \mathrm{ppm}$. Biocative compounds were identified in Halodule uninervis extract with ethyl acetate solvent extraction namely flavonoids, steroids, and triterpenoids while saponin compounds showed negative results. The results of the antidiabetic activuty from glucobay (control) are shown in Figure 2.

Glucobay is a commercial antidiabetic drug that can inhibit $\alpha$-glucosidase activity and is often recommended in diabetic patients. Testing of $\alpha$-glucosidase activity using glucobay as a positive control with concentrations of $0.1 \mathrm{ppm}, 0.5 \mathrm{ppm}, 1 \mathrm{ppm}, 5 \mathrm{ppm}$ and $10 \mathrm{ppm}$. Figure 4 can be seen that glucobay samples showed the smallest percentage inhibition value at a concentration of $0.1 \mathrm{ppm}$, which was $26.32 \%$. For $\mathrm{IC}_{50}$ values each solvent is found in Figure 4.

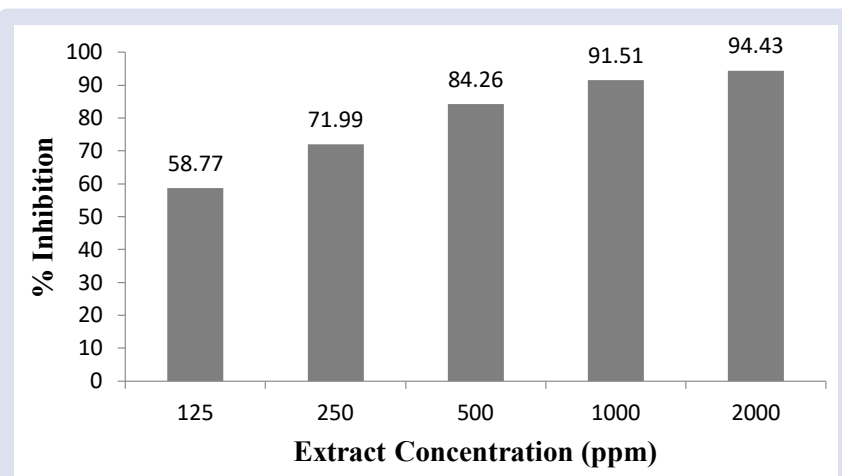

Figure 1: Antidiabetic activity of Halodule Uninervis extract with ethanol solvent.

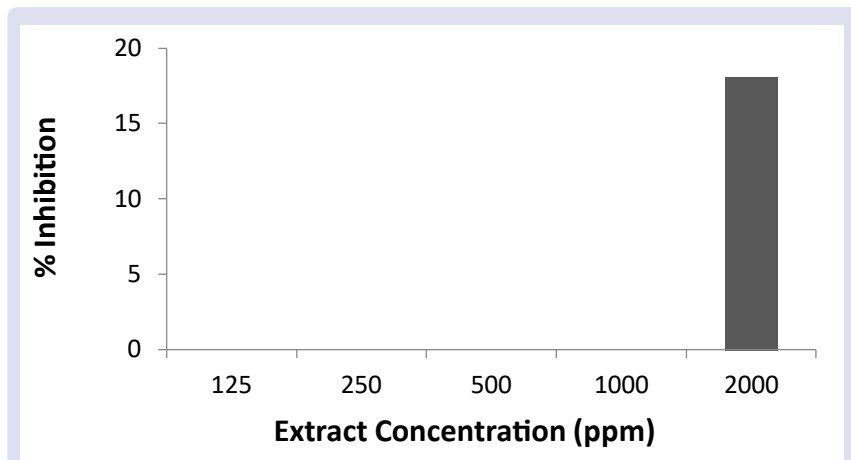

Figure 2: Antidiabetic activity of Halodule uninervis extract with ethyl acetate solvents.

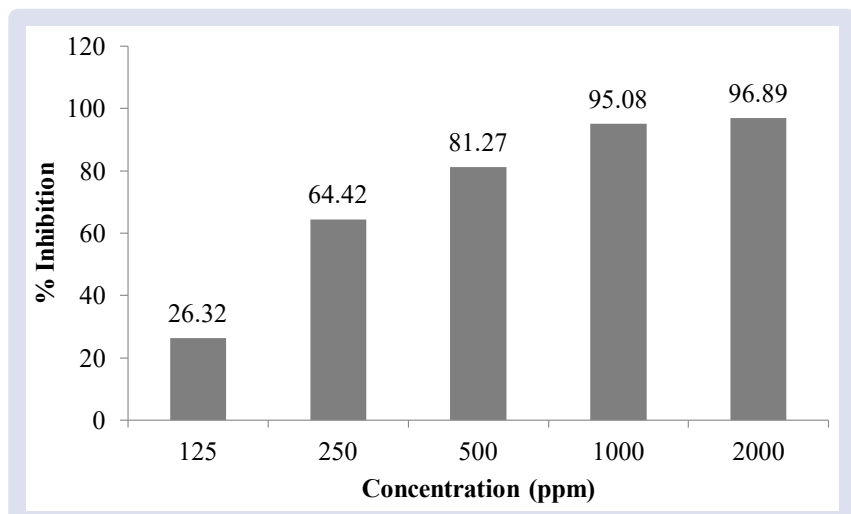

Figure 3: Inhibition of a-glucosidase enzymes from glucobay.

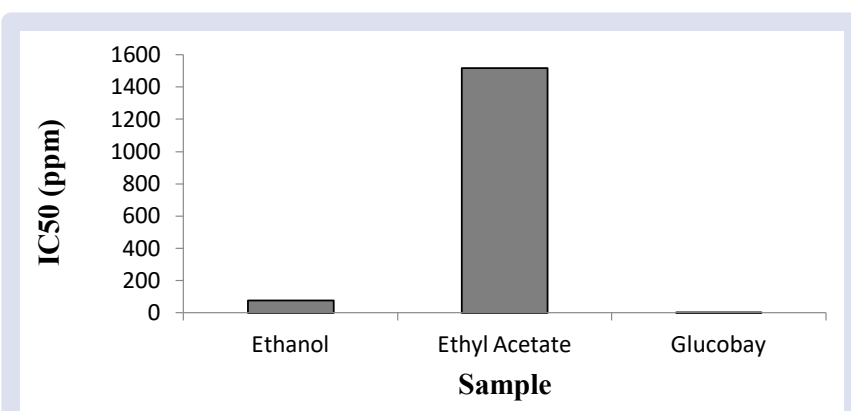

Figure 4: $I C_{50}$ value of Halodule uninervis extract with ethanol and ethyl acetate solvents and glucobay samples. 
The activity test was carried out to determine the inhibitory activity of sample extracts against $\alpha$-glucosidase from various extract concentrations by looking at the percent inhibition value and knowing the inhibitory strength of the enzyme by looking at the $\mathrm{IC}_{50}$ value. The IC50 value was determined by making a curve between percent inhibition and the concentration of mining samples so that the regression equation was obtained. From the regression equation can be determined the amount of extract concentration which has an inhibitory ability to a-glucosidase enzyme activity by $50 \%{ }^{13}$ Calculation of $\mathrm{IC}_{50}$ of Halodule uninervis seagrass with ethanol extract was 74.99 ppm, ethyl acetate extract was 1,517,05 ppm and glukobay as control was $0.27 \mathrm{ppm}$.

\section{CONCLUSION}

The content of antidiabetic activity with extract concentrations of 125 ppm, $250 \mathrm{ppm}, 500 \mathrm{ppm}, 1,000 \mathrm{ppm}$ and 2,000 ppm from seagrass extract with ethanol solvent showed that it had the ability as an antidiabetic agent stronger than seagrass extract with n-hexane and ethyl acetate solvents. Calculation of $\mathrm{IC}_{50}$ of Halodule uninervis seagrass was $74.99 \mathrm{ppm}$, which means that as much as $74.99 \mathrm{ppm}$ the sample can inhibit $50 \%$ of $a$-glucosidase activity.

\section{REFERENCES}

1. Du WQ, Shi XF, MY. Qiu MY. Progress in treatment of diabetes drugs. Chin Hosp Pharm J. 2005;25:67-9.

2. Playford RJ, Pither C, Gao R, Middleton SJ. Use of the $\alpha$-glucosidase inhibitor acarbose in patients with 'Middleton syndrome': normal gastric anatomy but with accelerated gastric emptying causing postprandial reactive hypoglycemia and diarrhea. Can J Gastroenterol. 2013;27:403-4.
3. Wadkar K, Magdum C, Patil S, Naikwade N. Antidiabetic potential and Indian medicinal plants. J Herbal Med Toxicol. 2008;2:45-50.

4. Grover JK, Yadav S, Vats V. Medicinal plants of India with anti-diabetic potential. J Ethnopharmacol. 2002;81:81-100.

5. Sambara ZR. Propagation of Rhizoma Seagrass Transplanted Multispesies on Barrang Lompo Island. Thesis. Faculty of Fisheries and Marine Sciences. University of Hasanuddin. Makassar. 2014

6. Kiswara W. Inventory and Evaluation of Sea-Coastal Potential II "Geology, Chemistry, Biology and Ecology. Center for Research and Development of Oceanology, Indonesian Institute of Sciences. Jakarta. 1997.

7. Gosari BAJ, Haris A. Study of seagrass density and closure in the Supermonde Islands. Torani. 2012;22(3):156-62

8. El-Shaffai A. Filed to seagrassess of the Red Sea. First Edition.France:Total Foundation. 2011.

9. Yudhi R. Antioxidant Bioactive Compound of Soft Coral (Sarcophyton sp.) Natural and Transplantation in Pramuka Island, Kepulauan Seribu. Thesis. Faculty of Fisheries and Marine Sciences, IPB University, Bogor. 2011.

10. Widuri SA, Noorcahyati, Puspanti A. Potential of Several Types of Antidiabetic Efficacy Plants by Kalimantan Ethnics as a Secondary Metabolite Source for the Development of Modern Medicine. Research Institute for Natural Resource Conservation Technology. Kalimantan Timur. 2011.

11. Purwatresna E. Antidiabetic Activity of In Vitro Water and Ethanol Soursop Leaves through Inhibition of $\alpha$-Glucosidase Enzymes. Thesis. Faculty of Fisheries and Marine Sciences, IPB University, Bogor. 2012.

12. Sancheti S. Chaenomeles sinensis: a potent $\alpha$-and $\beta$-glucosidase inhibitor. Am J Pharm Toxic. 2009;4(1):8-11.

13. Febrinda AE, Made A, Tutik W, Nancy DY. Antioxidant and Alpha-Glucosidase Inhibitory Properties of Bawang Dayak Bulb Extracts. Journal of Technology and Food Industry. 2013;34(2):161-7.

\section{GRAPHICAL ABSTRACT}

\section{ABOUT AUTHORS}

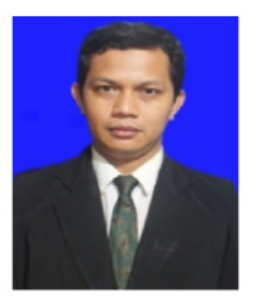

Dr. Ace Baehaki, S.Pi, M.Si, Associate Professor, Department of Fisheries Product Technology, Faculty of Agriculture, Sriwijaya University since 2001. His research area focuses on biological screening and bioactive activity of natural products from aquatic resources. 


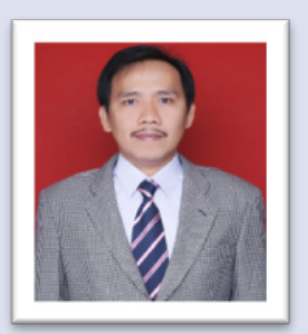

Herpandi, S.Pi, M.Si, Ph.D, Associate Professor, Department of Fisheries Product Technology, Faculty of Agriculture, Sriwijaya University since 2001. His research area focuses on biochemistry of fishery product

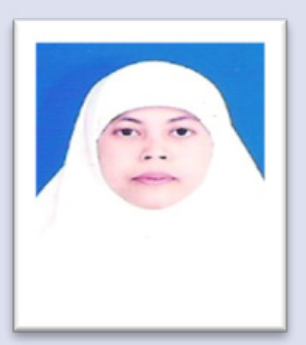

Susi Lestari, S.Pi, M.Si, Lecturer, Department of Fisheries Product Technology, Faculty of Agriculture, Sriwijaya University since 2001. Her research area focuses on fisheries product technology.

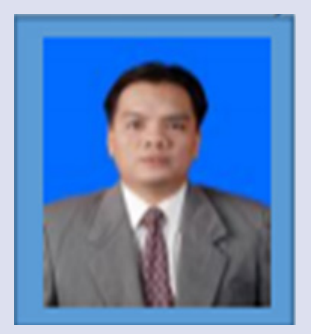

Dr. Muhammad Hendri, S.T, M.Si, Assistant Professor, Department of Marine Sciences, Faculty of Mathematics and Natural Sciences, Sriwijaya University. His research area focuses on bioactive activity of natural products from aquatic resources.

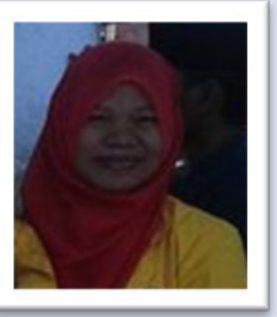

Febri Ariska, S.Pi, The researcher, Department of Fisheries Product Technology, Faculty of Agriculture, Sriwijaya University. Her research area focuses on fisheries product technology.

Cite this article: Baehaki A, Herpandi, Lestari S, Hendri M, Ariska F. Antidiabetic Activity with N-Hexane, Ethyl-Acetate and Ethanol Extract of Halodule uninervis Seagrass. Pharmacogn J. 2020;12(4):805-8. 